\title{
Integrated Effects of Vermi-compost and NPS Fertilizer Rates on Soil Chemical Properties and Maize Production in Bedele District, Western Oromia
}

\author{
Dagne Chimdessa, Gedefa Sori \\ Natural Resource Department, Oromia Agricultural Research Institute, Bedele, Ethiopia \\ Email address: \\ dagnechimdessa@yahoo.com (D. Chimdessa) \\ To cite this article: \\ Dagne Chimdessa, Gedefa Sori. Integrated Effects of Vermi-compost and NPS Fertilizer Rates on Soil Chemical Properties and Maize \\ Production in Bedele District, Western Oromia. Plant. Vol. 8, No. 4, 2020, pp. 115-121. doi: 10.11648/j.plant.20200804.15
}

Received: July 27, 2020; Accepted: August 10, 2020; Published: December 11, 2020

\begin{abstract}
Integrated plant nutrient management is the application of inorganic fertilizer in combination with organic fertilizer to maintain soil fertility and balance nutrient supply in order to boost up the crop yield per unit area. A study was conducted in Bedele District on farmers' fields to find out the combined effects of vermi-compost (organic fertilizer) and NPS (inorganic fertilizer) rates on soil chemical properties and maize production. The treatments consisted of three levels of vermicompost $\left(0,1.5\right.$ and $\left.3 \mathrm{tha}^{-1}\right)$ and three levels of NPS fertilizer $\left(0,100\right.$ and $\left.200 \mathrm{~kg} \mathrm{ha}^{-1}\right)$. The experiment was laid out in RCBD design in factorial combination with three replications. laboratory analysis results of composite soil samples collected before sowing showed deficiency in soil chemical properties. However, analysis of variance of post harvest composite soil samples collected from each plot indicated significant differences on soil available $\mathrm{P}, \mathrm{OC}, \mathrm{TN}$ and CEC while, soil $\mathrm{pH}$ and exchangeable acidity showed positive improvement as compared to initial soil sample. The analysis of variance among the treatments showed significant differences $(\mathrm{P} \leq 0.05)$ on almost all the maize characters tested. The highest and lowest maize grain yield $\left(7932.1 \mathrm{~kg} \mathrm{ha}^{-1}\right)$ and $\left(1944.4 \mathrm{~kg} \mathrm{ha}^{-1}\right)$ were obtained from the treatment combination of $3 \mathrm{t} \mathrm{ha}{ }^{1}$ vermi-compost with $200 \mathrm{~kg} \mathrm{ha}^{-1}$ NPS and $92 \mathrm{~kg} \mathrm{ha}^{-1} \mathrm{~N}$, and control plot, respectively. However this combination was statically at par with the treatment combination of $1.5 \mathrm{t} \mathrm{ha}^{-1}$ vermi-compost with $200 \mathrm{~kg} \mathrm{ha}^{-1} \mathrm{NPS}$ and $92 \mathrm{~kg} \mathrm{ha}^{-1} \mathrm{~N}$, which gave maize grain yield $\left(7577.2 \mathrm{~kg} \mathrm{ha}^{-1}\right)$. Therefore, the present study showed that combined fertilization of vermi-compost and NPS fertilizer enhanced maize productivity and soil fertility status in the study area; indicated that maize productivity in the study sites were reduced due to high demand for external nutrient inputs. Hence combined fertilization of $1.5 \mathrm{t} \mathrm{ha}^{1}$ vermi-compost with $200 \mathrm{~kg}$ $\mathrm{ha}^{-1} \mathrm{NPS}$ and $92 \mathrm{~kg} \mathrm{ha}^{-1} \mathrm{~N}$ could improve maize productivity and soil chemical properties, and recommended for the study area (Bedele District) and similar agro-ecology. The result also showed that the soils of the study sites had poor chemical fertility and integrated soil fertility management practices can improve the current situation.
\end{abstract}

Keywords: Cation Exchange Capacity, Soil Organic Carbon, Soil pH, Total Nitrogen, Vermi-Compost

\section{Introduction}

The loss of soil fertility from continual nutrient mining by crop removal without adequate replenishment, combined with imbalanced plant nutrition practices, has posed a serious threat to agricultural production [1]. Continuous cultivation of soils for many years without replenishing the nutrients mined has negatively affected fertility and availability of nutrients. [2]. also stated that cultivated weathered soils commonly suffer from multiple nutrient deficiencies, and nutrient balances are generally negative. The low nutrient levels in the soil are caused by crop removal of nutrients from the soil, little or no fertilizer application, and total removal of crop residues from the farmland and burning. Nowadays, due to increasing population pressure and shortage of land, deforestation and cultivation activities are being carried out on steep slopes, which accelerate soil erosion [3, 4]. Moreover, the shortage of land for production of food crops has eliminated the practice of fallowing and crop rotation. Furthermore, shortage of grasslands (grazing areas) has forced the farmers to remove crop residues for animal feed. These lead to agricultural soil degradation with detrimental effects on the physical, chemical and biological properties of soils [5]. 
Soil fertility and functioning must be restored to provide sustainable farming systems. As alternative, solutions for increasing soil organic matter have been proposed. [6, 7] recommended regular inputs of organic amendments to soil while other authors advocated the use of improved fallows to restore organic matter to soil [8,9]. These agricultural management methods are known to enhance the stock of soil carbon [10]. It is well established that organic matter plays a central role in maintaining key soil functions and is an essential determinant of soil fertility and resistance to erosion. Several authors have found that organic inputs increase soil microbial biomass $[11,12]$ and enzyme activities $[13,14])$ and enhance microbial activity [15]. The application of organic amendments can, therefore, affect the activity, structure, diversity and function of soil microorganisms, which play a key role in soil processes to a greater extent.

Vermi-compost is the recently organic fertilizer in supplementing chemical fertilizers for sustainable development of agriculture [16]. It is produced through the interaction between earthworm and microorganism by the breakdown of organic wastes. It is a stabilized, finely-divided peat-like material with a low $\mathrm{C}$ : $\mathrm{N}$ ratio and high water holding capacity that constitute a source of plant nutrition which is released gradually through mineralization whenever the plant needs it [17]. It is a material that characterized by high porosity, aeration, drainage, water holding capacity and microbial activity [18]. Vermi-compost can influence the growth and productivity of plants significantly [19]. It increase soil organic carbon, nitrates, phosphates, exchangeable calcium and some other nutrients for plants (Orozco et al., 1996). It increases soil Cation Exchange Capacity (CEC) and crop yield [20]. The available nutrient status of soil was greatly enhanced by the application of vermicompost as an organic source [21]. Vermi-compost enhanced phosphorous concentration and uptake in soil, increasing the solubilisation of phosphorous either by microorganism activation with excretion of organic acids likes citric, glutamic, tartaric, succinic, lactic, oxalic, malic and fumaric [22]. It can improve physical, chemical and biological and processes of soil which have their bearings on plant's growth [23].

On the other hand, inorganic fertilizers overcome soilfertility problems and responsible for increasing large partof worlds food production [24]. Increment of crop yield from 30 to $50 \%$ has resulted from application of commercial fertilizers $[25,26]$. Crop yields in the developed world are high and agricultural soils have high fertility status due to intensive use of fertilizers [27]. This implies that using chemical fertilizer plays significant role in increasing food production to meet the demand of the growing world population. Similarly, Vermi-compost is increasingly considered in agriculture as a promising alternative to chemical fertilizers. However, the effects of vermi-compost either alone or integrated with chemical fertilizers, on the crop productivity is not yet fully understood. Therefore, integrated plant nutrients management can lessen this problem and can be suitable for any farming system and socio-economic conditions [28]. Integrated plant nutrient management is the application of inorganic fertilizer in combination with organic fertilizer to maintain soil fertility and to balance nutrient supply in order to boost up the crop yield per unit area [29-31].

Moreover, Ethiopia has realized that agricultural soils commonly suffer from multiple nutrient deficiencies, and nutrient balances are generally negative, and an effort has been made to increase soil fertility status; among which vermi-compost (organic fertilizer) is one of it. Similarly vermi-worms are distributed to local farmers' and they started producing vermi- compost. However, in the study area there is no information on the combined use of vermi-compost and chemical fertilizer for maize production. Therefore, the objective of the study was to find out the combined effects of vermi-compost (organic fertilizer) and NPS (inorganic fertilizer) rates on soil chemical properties and maize production in Bedele District.

\section{Materials and Methods}

\subsection{Description of the Study Area}

The study was conducted on three farmers' fields in Bedele District of Buno Bedele zone in 2019 main cropping season. Bedele District is located at $08^{\circ} 14^{\prime} 28.6^{\prime \prime}$ to $08^{\circ} 37^{\prime} 52.8^{\prime \prime} \mathrm{N}$ and $036^{\circ} 13$ '22.0" to $036^{\circ} 35^{\prime} 09.1^{\prime \prime}$ E. The 18 years weather information at nearby study area (Ethiopian Metrology Agency Bedele District Branch) indicated that a uni-modal rainfall pattern with average annual rain fall of $1945 \mathrm{~mm}$. The rainy season covers April to October and the maximum rainfall is received in the months of June, July and August. The minimum and maximum annual air temperatures are 12.9 and $25.8 .0^{\circ} \mathrm{C}$, respectively, The predominant soil type in southwest and western Ethiopia in general and the study area in particular, is Nitisols according to the [32] soil classification system. Its vernacular name is "Biyyee Dimmaa" meaning red soil. On the average, the soil is deep and relatively highly weathered, well drained, clay in texture and strongly to moderately acidic in reaction. Nitisols are highly weathered soils in the warm and humid areas of the west and southwest Ethiopia [33].

\subsection{Soil Sampling and Analysis}

Composite surface soil samples (0-20) $\mathrm{cm}$ depth were collected from each experimental sites before sowing and intensive soil samples were collected from each experimental plot after harvest to analyze soil $\mathrm{pH}\left(\mathrm{H}_{2} \mathrm{O}\right)$, exchangeable acidity, available $\mathrm{P}$ (Olsen), (OC\%), (TN\%), and CEC. The collected soil samples were prepared and analyzed following standard laboratory procedures at soil analysis laboratory of, Bedele Agricultural Research Center.

\subsection{Treatments, Experimental Design and Procedures}

The treatments consisted of three levels of vermi-compost $(0$, 1.5 and $\left.3 \mathrm{tha}^{-1}\right)$ and three levels of NPS fertilizer (0, 100 and $200 \mathrm{~kg} \mathrm{ha}^{-1}$ ) were arranged in randomized complete block design $(\mathrm{RCBD})$ in a factorial combination with three replications The total number of treatment were nine. The gross plot size was $12 \mathrm{~m}^{2}(3 \mathrm{~m} \times 4 \mathrm{~m})$ that accommodated five maize plants rows. 
Hybrid maize (BH 661) which is high yielder as compared to other improved maize varieties in the study areas was used as a test crop in the District, that was planted in rows with spacing of $80 \mathrm{~cm}$ between rows and $25 \mathrm{~cm}$ among plants within a row. The experimental fields were prepared by using oxen plow in accordance with conventional farming practices followed by the farming community in the area where, the fields were plowed four times., and treated with lime for soil $\mathrm{pH}$ less than 5.5, and the amount of lime needed per hectare was calculated based on the formula LR $=$ Ex. acidity* $1.5 * 10 \mathrm{kun} \mathrm{ha}^{-1}$. Full dose of vermi-compost and NPS fertilizer as per the treatment and onehalf of $\mathrm{N}$ was applied at sowing. The remaining one-half of $\mathrm{N}$ was top dressed at 35 days after planting in the form of urea. The field was kept free of weeds by hand weeding during the period of the experiment. All other recommended agronomic management practices disease and insect pest control were done.

Finally, days to $50 \%$ tasseling, biomass and grain yields were collected. Data on plant basis was recorded from the three central rows out of the five rows per plot. The collected data was subjected to analysis of variance using SAS software. Mean separation was done by LSD..

\section{Results and Discussion}

\subsection{Effects of Vermi-compost and NPS Fertilizer Rates on Soil pH, Exchangeable Acidity, Available P, OC, TN, and CEC Status After Maize Harvest}

Post harvest soil $\mathrm{pH}$, exchangeable acidity, available $\mathrm{P}$, OC, TN, and CEC are presented in (Table 1). The results indicate that there were no significant $(\mathrm{P}<0.05)$ differences in soil $\mathrm{pH}$ and exchangeable acidity among the different vermi-compost and NPS fertilizer rates. The treatments were statistically similar, however, the greatest positive $\mathrm{pH}$ value (5.20) changed from the initial $\mathrm{pH}$ of 4.90 was recorded for vermi-compost rate at $3 \mathrm{tha}^{-1}$ and no NPS fertilizer. The lowest negative $\mathrm{pH}$ changed from the initial soil $\mathrm{pH}$ was recorded for control treatment which gave $\mathrm{pH}$ value of 4.91 . Whereas, exchangeable acidity decreased from 0.95 to 0.27 at 1.5 tha $^{-1}$ vermi-compost and $100 \mathrm{kgha}^{-1}$ NPS fertilizer rates. The status of soil $\mathrm{pH}$ and exchangeable acidity were improved in this study indicated that, addition of lime and Vermi-compost to the experimental sites were effective in increasing soil $\mathrm{pH}$, which realized that soil $\mathrm{pH}$ is considered a master variable in soils as it controls many chemical processes that take place. It specifically affects plant nutrient availability by controlling the chemical forms of the nutrients.

The results also indicate that there were significant $(\mathrm{P}<$ 0.05 ) difference in soil available $\mathrm{P}, \mathrm{OC}, \mathrm{TN}$, and CEC. The status of soil available $\mathrm{P}$ after harvest was greatly enhanced as compared to initial $\mathrm{P}$ before sowing (Table 1), indicated that Vermi-compost enhanced phosphorous concentration and uptake in soil, increasing the solubilisation of phosphorous either by microorganism activation with excretion of organic acids likes citric, glutamic, tartaric, succinic, lactic, oxalic, malic and fumaric [22]. Plants only absorb approximately $20-30 \%$ of $\mathrm{P}$ in applied fertilizers each year [34]. In general a small proportion of applied $\mathrm{P}$ is immediately taken up by the plants and the remaining $\mathrm{P}$ accumulates in the soil, which is potentially available for uptake by crops in subsequent years. Vermi-compost increases soil organic carbon, nitrates, phosphates, exchangeable calcium and some other nutrients for plants [35]. Vermi-compost increases soil Cation Exchange Capacity (CEC) and crop yield [20]. Cation exchange capacity is highly correlated with organic carbon (OC) content of the soil, which is in turn, is affected by different soil management practices such as intensive cultivation, fertilization, and changes in land use [36]. Cation exchange capacity increases with increasing soil OM [37]. It is strongly affected by the nature and amount of mineral and organic colloids present in the soil. Thus, CEC measurements are commonly made as part of the overall assessment of the potential fertility of a soil, and possible response to fertilizer application [38]. In conclusion the available nutrient status of soil was greatly enhanced by the application of vermicompost as an organic source [21].

Table 1. Effects of vermi-compost and NPS fertilizer rates on soil chemical properties aftermaize harvest.

\begin{tabular}{|c|c|c|c|c|c|c|c|}
\hline \multicolumn{4}{|c|}{ Treatments } & \multicolumn{4}{|c|}{ Soil properties } \\
\hline \multirow{2}{*}{$\begin{array}{l}\text { V. Com } \\
\text { (ton/ha) }\end{array}$} & \multirow{2}{*}{$\begin{array}{l}\text { NPS } \\
\text { (kg/ha) }\end{array}$} & pH & Ex.acid & Pav & OC & TN & CEC \\
\hline & & $\left(\mathrm{H}_{2} \mathrm{O}\right)$ & meq/100gm soil) & (ppm) & $\%$ & $\%$ & $(\mathrm{cmol}(+) / \mathrm{kg}$ soil) \\
\hline 0 & 0 & $4.91^{\mathrm{a}}$ & $0.40^{\mathrm{a}}$ & $2.00^{\mathrm{bc}}$ & $3.02^{\mathrm{c}}$ & $0.26^{\mathrm{c}}$ & $12.33^{\mathrm{bc}}$ \\
\hline 1.5 & 0 & $5.00^{\mathrm{a}}$ & $0.40^{\mathrm{a}}$ & $3.20^{\mathrm{a}}$ & $3.53^{\mathrm{bc}}$ & $0.30^{\mathrm{bc}}$ & $15.96^{\mathrm{ab}}$ \\
\hline 3 & 0 & $5.20^{\mathrm{a}}$ & $0.30^{\mathrm{a}}$ & $2.13^{\mathrm{abc}}$ & $3.36^{\mathrm{c}}$ & $0.26^{\mathrm{c}}$ & $17.46^{\mathrm{a}}$ \\
\hline 0 & 100 & $5.17^{\mathrm{a}}$ & $0.30^{\mathrm{a}}$ & $3.00^{\mathrm{ab}}$ & $3.06^{\mathrm{c}}$ & $0.26^{\mathrm{c}}$ & $14.53^{\mathrm{abc}}$ \\
\hline 1.5 & 100 & $5.17^{\mathrm{a}}$ & $0.27^{\mathrm{a}}$ & $2.01^{\mathrm{bc}}$ & $3.30^{\mathrm{c}}$ & $0.30^{\mathrm{bc}}$ & $14.46^{\mathrm{abc}}$ \\
\hline 0 & 200 & $5.10^{\mathrm{a}}$ & $0.37^{\mathrm{a}}$ & $2.87^{\mathrm{abc}}$ & $3.26^{\mathrm{c}}$ & $0.30^{\mathrm{bc}}$ & $17.03^{\mathrm{a}}$ \\
\hline 1.5 & 200 & $5.13^{\mathrm{a}}$ & $0.40^{\mathrm{a}}$ & $2.40^{\mathrm{abc}}$ & $3.66^{\mathrm{bc}}$ & $0.33^{\mathrm{abc}}$ & $12.50^{\mathrm{bc}}$ \\
\hline 3 & 200 & $5.17^{\mathrm{a}}$ & $0.33^{\mathrm{a}}$ & $1.80^{\mathrm{c}}$ & $4.60^{\mathrm{a}}$ & $0.40^{\mathrm{a}}$ & $10.76^{\mathrm{c}}$ \\
\hline Mean & & 5.11 & 0.35 & 2.38 & 3.54 & 0.31 & 14.41 \\
\hline $\mathrm{CV}(\%)$ & & 2.36 & 44.9 & 27.36 & 11.13 & 14.17 & 15.35 \\
\hline LSD & & ns & ns & 1.12 & 0.68 & 0.07 & 3.83 \\
\hline Initial (be & wing) & 4.90 & 0.95 & 1.82 & 3.12 & 0.25 & 14.20 \\
\hline
\end{tabular}

Where, means followed by the same letters in each column are not significantly different at $(\mathrm{P} \leq 0.05)$, V.com $=$ Vermi-compost, CV $=\mathrm{Coefficient}$ of Variation, $\mathrm{LSD}=$ Least Significant Difference, Pav.=Available Phosphorus, OC=Organic Carbon, $\mathrm{TN}=$ Total Nitrogen, ppm=Part per million, Ex.acid $=$ Exchangeable acidity, $\mathrm{CEC}=$ Cation Exchange Capacity, $\mathrm{Ca}=$ Calcium, $\mathrm{t}=$ ton. 


\subsection{Mean Days to tasseling of Maize (BH 661) Under the Effect of Vermi-compost and NPS Fertilizer Rates}

The analysis of variance for days to tasseling revealed significant variation due to main effect of NPS fertilizer rates. However, application of vermi-compost rates did not show significant effect on days to tasseling. Vermi-compost can influence the growth and productivity of plants [19]. Concerning interaction effect of vermi-compost and NPS, the highest days to tasseling of 92.3 days was obtained with the un fertilized treatment, whereas the lowest ( 88.2 days) was obtained with the combination of $1.5 \mathrm{t} \mathrm{ha}^{-1}$ vermi-compost and $200 \mathrm{~kg} \mathrm{ha}^{-1}$ NPS (Table 2).

Table 2. Mean days to tasseling of maize (BH 661) under the effect of vermi-compost and NPS fertilizer rates.

\begin{tabular}{|c|c|c|c|c|}
\hline \multirow{2}{*}{ NPS } & \multicolumn{3}{|c|}{$\operatorname{VC}\left(\mathrm{t} \mathrm{ha}^{-1}\right)$} & \multirow{3}{*}{ Mean } \\
\hline & $\mathbf{0}$ & 1,5 & 3 & \\
\hline$\left(\mathrm{kg} \mathrm{ha}^{-1}\right)$ & \multicolumn{3}{|c|}{ Days to tassling (days) } & \\
\hline 0 & $92.3^{\mathrm{a}}$ & $91.5^{\mathrm{ab}}$ & $91.6^{\mathrm{ab}}$ & $91.8^{\mathrm{a}}$ \\
\hline 100 & $89.8^{\mathrm{abc}}$ & $89.2^{\mathrm{bc}}$ & $89.0^{\mathrm{bc}}$ & $89.4^{\mathrm{b}}$ \\
\hline 200 & $89.4^{\mathrm{bc}}$ & $88.2^{\mathrm{c}}$ & $89.2^{\mathrm{c}}$ & $88.9^{\mathrm{b}}$ \\
\hline Mean & $90.6^{\mathrm{a}}$ & $89.7^{\mathrm{a}}$ & $89.9^{\mathrm{a}}$ & \\
\hline CV $(\%)$ & 3.3 & & & \\
\hline LSD for VC & 1.6 & & & \\
\hline LSDforNPS * VC & 2.7 & & & \\
\hline
\end{tabular}

Where, means followed by the same letters are not significantly different at $(\mathrm{P} \leq 0.05), \mathrm{VC}=$ vermi-compost, $\mathrm{t}=$ ton, ha=hectare, $\mathrm{NPS}=($ nitrogen, $\mathrm{phosphorus}$, sulfur), $\mathrm{kg}=$ kilogram, $\mathrm{DH}=$ days to headings, $\mathrm{CV}=$ Coefficient of variation, $\mathrm{LSD}=$ Least significant differences.

\subsection{Mean Biomass Yield of Maize Under the Effect of Vermi-compost and NPS Fertilizer Rates}

Biomass yield was significantly $(\mathrm{P}<0.05)$ affected both by the main effects and the interaction between these factors (Table 3). This might be due to adequate quantities and balanced proportions of plant nutrients in vermi-compost supplied to the crop as per its need during the growth period resulting in favorable increase in yield attributing characters [39]. The effect of NPS fertilization on maize biomass yield was found to be significant (Table 3). Biomass yield increased consistently with NPS rates where the maximum biomass yield $\left(23366.8 \mathrm{~kg} \mathrm{ha}^{-1}\right)$ was obtained from the application of the highest NPS rate (200 kg ha ${ }^{-1}$ NPS) followed by $16386.3 \mathrm{~kg}$ $\mathrm{ha}^{-1}$ which was obtained from $100 \mathrm{~kg} \mathrm{ha}{ }^{-1}$ NPS and the minimum (9940.8 $\mathrm{kg} \mathrm{ha}^{-1}$ ) was from the control plot (Table 3)

Generally, biomass yield increased with increasing application rates of both vermi-compost and NPS fertilizer and decreased with the application of the minimum rates of these nutrient sources. Vermi-compost can influence the growth and productivity of plants significantly [19]. Moreover, the interaction effect of these factors also revealed that the combinations of higher rates of both the organic and inorganic nutrient sources gave significantly higher biomass yield of maize. This indicated that, vermi-compost plays a major role in improving growth and yield of different field crops, vegetables, flowers and fruits [40].

Table 3. Mean biomass yield of maize under the effect of vermi-compost and NPS fertilizer rates.

\begin{tabular}{|c|c|c|c|c|}
\hline \multirow{2}{*}{ NPS } & \multicolumn{3}{|c|}{ VC $\left(\mathrm{t} \mathrm{ha}^{-1}\right)$} & \multirow{3}{*}{ Mean } \\
\hline & 0 & 1,5 & 3 & \\
\hline$\left(\mathrm{kg} \mathrm{ha}^{-1}\right)$ & \multicolumn{3}{|c|}{ Bio mass yield $\left(\mathrm{kg} \mathrm{ha}^{-1}\right)$} & \\
\hline 0 & $7261^{\mathrm{e}}$ & $10664^{\mathrm{d}}$ & $11898^{\mathrm{d}}$ & $9940.8^{c}$ \\
\hline 100 & $16435^{\mathrm{c}}$ & $15756^{\mathrm{c}}$ & $16968^{c}$ & $16386.3^{b}$ \\
\hline 200 & $20957^{\mathrm{b}}$ & $22840^{\mathrm{b}}$ & $26304^{\mathrm{a}}$ & $23366.8^{\mathrm{a}}$ \\
\hline Mean & $14884.3^{\mathrm{b}}$ & $16419.8^{b}$ & $18389.9^{\mathrm{a}}$ & \\
\hline CV $(\%)$ & 21.2 & & & \\
\hline LSD for VC & 1910.7 & & & \\
\hline LSDforNPS * VC & 3309.5 & & & \\
\hline
\end{tabular}

Where, means followed by the same letters are not significantly different at $(\mathrm{P} \leq 0.05), \mathrm{VC}=$ vermi-compost, $\mathrm{t}=\mathrm{ton}, \mathrm{ha}=$ hectare, NPS $=($ nitrogen, phosphorus, sulfur), $\mathrm{kg}=$ kilogram, $\mathrm{DH}=$ days to headings, $\mathrm{CV}=$ Coefficient of variation, $\mathrm{LSD}=$ Least significant differences.

\subsection{Mean Grain Yield of Maize Under the Effect of Vermi-compost and NPS Fertilizer Rates}

Table 4 presents the means of maize grain yield as influenced by different application rates of NPS and Vermicompost. The analysis of variance indicated significant $(\mathrm{P}<0.05)$ grain yield differences due to the application of vermi-compost, NPS and their interactions. Vermi-compost is the recently organic fertilizer in supplementing chemical fertilizers for sustainable development of agriculture [16]. Increasing NPS levels from 0 to $200 \mathrm{~kg} \mathrm{ha}^{-1}$ showed linear and consistent yield increment. The average maize grain yield for the NPS treatments ranged from 2649.2 to 7443.4 $\mathrm{kg} \mathrm{ha}^{-1}$ NPS with a yield increment of 26 to $74 \%$ over the control treatment, respectively. Increasing vermi-compost 
rate didn't show significant grain yield differences except control (Table 4).

Concerning the interaction effect of vermi-compost and NPS, the highest grain yield $\left(7932.1 \mathrm{~kg} \mathrm{ha}^{-1}\right)$ was obtained from the combination of $3 \mathrm{t} \mathrm{ha}^{-1}$ vermi-compost and $200 \mathrm{~kg}$ $\mathrm{ha}^{-1}$ NPS, however statically at par with $1.5 \mathrm{t} \mathrm{ha}^{-1}$ vermicompost and $200 \mathrm{~kg} \mathrm{ha}^{-1}$ NPS. The lowest (1944.4 $\mathrm{kg} \mathrm{ha}^{-1}$ ) was obtained with the un fertilized treatment (Table 4). The highest yield for the interaction effect could be due to vermi- compost promotes better root growth, nutrient absorption and improves nutrient status of soil, both macro-nutrients and micro-nutrients [41]. The growth and nutrient status of crops have revealed a positive effect on plant nutrition, photosynthesis, chlorophyll content and nutrient content of different plant components namely roots, shoots and fruits [42]. In conclusion Vermi-compost is the recently organic fertilizer in supplementing chemical fertilizers for sustainable development of agriculture.

Table 4. Mean grain yield of maize under the effect of vermi-compost and NPS fertilizerrates.

\begin{tabular}{|c|c|c|c|c|}
\hline \multirow{2}{*}{ NPS } & \multicolumn{3}{|c|}{ VC $\left(\mathrm{t} \mathrm{ha}^{-1}\right)$} & \multirow{3}{*}{ Mean } \\
\hline & $\mathbf{0}$ & 1,5 & 3 & \\
\hline$\left(\mathrm{kg} \mathrm{ha}^{-1}\right)$ & \multicolumn{3}{|c|}{ Grain yield $\left(\mathrm{kg} \mathrm{ha}^{-1}\right)$} & \\
\hline 0 & $1944.4^{\mathrm{e}}$ & $2762.3^{\mathrm{de}}$ & $3240.7^{d}$ & $2649.2^{c}$ \\
\hline 100 & $4753.1^{\mathrm{c}}$ & $5108.0^{\mathrm{c}}$ & $5416.7^{c}$ & $5092.6^{\mathrm{b}}$ \\
\hline 200 & $6821.0^{\mathrm{b}}$ & $7577.2^{\mathrm{ab}}$ & $7932.1^{\mathrm{a}}$ & $7443.4^{\mathrm{a}}$ \\
\hline Mean & $4506.2^{b}$ & $5149.2^{\mathrm{a}}$ & $5529.8^{\mathrm{a}}$ & \\
\hline CV $(\%)$ & 21.4 & & & \\
\hline LSDforNPS & 587.8 & & & \\
\hline LSD for VC & 587.8 & & & \\
\hline LSDforNPS * VC & 1018.2 & & & \\
\hline
\end{tabular}

Where, means followed by the same letters are not significantly different at $(\mathrm{P} \leq 0.05), \mathrm{VC}=$ vermi-compost, $\mathrm{t}=$ ton, ha=hectare, $\mathrm{NPS}=($ nitrogen, $\mathrm{phosphorus,}$ sulfur), $\mathrm{kg}=$ kilogram, $\mathrm{DH}=$ days to headings, $\mathrm{CV}=$ Coefficient of variation, $\mathrm{LSD}=$ Least significant differences

\section{Conclusions and Recommendation}

Integrated nutrient management for crop production requires that quantitative information on all nutrient sources be made available. Organic fertilizers maintains soil health, improves soil nutrient exchange and it typically mineralized within only a few cropping seasons to obtain a sustainable and stable increase in yield while, the inorganicfertilizer is the immediate source for crop. One test to evaluate the effects of organic nutrient sources on soil fertility is obviously to measure yields over the long-term, because it takes years for the yield to consistently reflect improved soil fertility status. This presumably has been reflected on the soil parameters in the current study. Laboratory analysis results of soil samples collected before sowing showed deficiency in soil chemical properties. However, post harvest soil samples indicated that significantly difference and positive increment on soil fertility status tested.. The analysis of variance among the treatments showed significant differences on maize characters tested. Accordingly, combined fertilization of vermi-compost and NPS fertilizer enhanced soil fertility status and maize productivity in the study area; which indicated that maize productivity in the study sites were reduced due to high demand for external nutrient inputs. In conclusion, based on the data obtained from this study combined fertilization of $1.5 \mathrm{t} \mathrm{ha}^{1}$ vermi-compost with $200 \mathrm{~kg}$ NPS ha ${ }^{-1}$ fertilizer and $92 \mathrm{~kg} \mathrm{~N} \mathrm{ha}^{-1}$ are recommended for maize production to the study area (Bedele District) and similar agro-ecology. To sustain and/or improve the current unbalanced fertilizer application and soil mining of the study sites, precautionary actions such as adopting sustainable soil fertility replenishment strategy, soil conservation practices, lime application and avoiding unbalanced fertilizers can help to rebuild the soil conditions to increase crop productivity. Further researches have to be continued to recommend rate, time and method of combined application of vermi-compost and NPS fertilizer for major crops grown in this region.

\section{Acknowledgements}

We acknowledge GIZ- ISFM, Oromia Agricultural Research Institute (OARI) and Agricultural Growth Program (AGP II) for granting research fund and technical advice.

\section{References}

[1] FAO (Food and Agriculture Organization), 2006. Plant nutrition for food security: A guide for integrated nutrient management. FAO, Fertilizer and Plant Nutrition Bulletin 16. FAO, Rome.

[2] Mokwunye, A. U., A. de Jager and E. M.. Smailing, 1996. Restoring and maintaining the productivity of West Africa Soils: Key to sustainable development. International Fertilizer Development Center (IFDC), Muscle Shoals, Alabama. 94p.

[3] Tolessa Debelle, Tesfa Bogale, Wakene Negassa, Tenaw Worayehu, Minale Liben, Tewodros Mesfin. Birtukan Mekonen and Waga Mazengia, 2001. A review of fertilizer management research on maize in Ethiopia. Enhancing the contribution of maize to food security in Ethiopia. Proceedings of the second National maize workshop of Ethiopia. 12-16 November 2001, Addis Ababa, Ethiopia.

[4] Matano, A.-S., Kanangire, C. K., Anyona, D. N., Abuom, P. O., Gelder, F. B., Dida, G. O., Owuor, P. O. and Ofulla, A. V. O. (2015) Effects of Land Use Change on Land Degradation Reflected by Soil Properties along Mara River, Kenya. 
[5] Rivero, C., Chirenje, T., Ma, L. Q. and Martinez, G. (2004) Influence of Compost on Soil Organic Matter Quality under Tropical Conditions. Geoderma, 123, 355-361.

[6] Bationo, A., Lompo, F. and Koala, S. (1998) Research on Nutrient Flows and Balances in West Africa: State-of-the- Art. In: Smaling, E. M. A., Ed., Nutrient Balances as Indicators of Production and Sustainability in Sub-Saharan African Agricultural, Agriculture, Ecosystems \& Environment, 71, 1936.

[7] Badiane, A. N., Khouma, M. and Sene, M. (2000) Région de Diourbel: Gestion des sols. Drylands Research Working Paper 15, Drylands Research, Somerset, 25 p.

[8] Dominguez, J. (2004) State-of-the-Art and New Perspectives on Vermicomposting Research. In: Edwards. C. A., Ed., Earthworm Ecology, CRC Press LLC, Boca Raton, 401-424.

[9] Arancon, N. Q. and Edwards, C. A. (2005) Effects of Vermicomposts on Plant Growth. Soil Ecology Laboratory, The Ohio State University, Columbus.

[10] Ndegwa, P. M. and Thompson, S. A. (2001) Integrating Composting and Vermicomposting in theTreatment and Bioconversion of Biosolids. Bioresource Technology, 76, 107112.

[11] Walkley, A. and Black, I. A. (1934) An Examination of Degtja-Reff Method for Determining Soil Organic Matter and a Proposed Modification of the Chromic Acid Titration Method. Soil Science, 37, 29-38.

[12] Tognetti, C., Laos, F., Mazzarino, M. J. and Hernández, M. T. (2005) Composting vs. Vermicomposting: A Comparison of End Product Quality. Compost Science and Utilization, 13, 613 .

[13] Masto, R. E., Chhonkar, P. K., Singh, D. and Patra, A. K. (2006) Changes in Soil Biological and Biochemical Characteristicsin a Long-Term Field Trial on a Sub-Tropical Inceptisol. Soil Biology \& Biochemistry, 38, 1577-1582.

[14] Koné, W. A., Edoukou, E. F., Gonnety, T. J., N'Dri, A. A. N., Assémien, E. F. L., Angui, K. T. P. and Tondoh, E. J. (2012) Can the Shrub Chromolaenaodorata (Asteraceae) Be Considered as Improving Soil Biology and Plant Nutrient Availability. Agroforestry Systems, 85, 233-245.

[15] Hungria, M., Franchini, J. C., Brandao-Junior, O., Kaschuk, G. and Souza, R. A. (2009) Soil Microbial Activity and Crop Sustainability in a Long-Term Experiment with Three SoilTillage and Two Crop-Rotation Systems. Applied Soil Ecology, 42, 288-296.

[16] Gupta PK (2003). Vermicomposting for sustainable agriculture. Agrobios 188.

[17] Mathivanan S, Chidambaram AL A, Sundaramoorthy P, Kalaikandhan R.(2012) Effect of vermicompost on germination and biochemical constituents of ground nut (Arachis hypogea L.) seedling. Int JRes BiolSci, 2012; 2 (2): 54-59.

[18] Atiyeh, R. M., Arancon, N, Edwards, C. A and Metzger, T. D. 2000. Influence of earthworm processed pig mature on the growth and yield of greenhouse tomatoes. Sci. Direst, 75: 175-180.

[19] Edwards, C. A. 1998. The use of earthworm in the breakdown and management of Organic wastes. In: earthworm ecology. Edwards, C. A (eds). CRC press LLC, Boca Raton, F1, ISBN: 84931819X, PP: 327-354.
[20] Marinari, S., Masciandaro, G., Ceccanti, B. and Grero, S. 2000. Influence of organic and mineral fertilizers on soil biological and physical properties. Bioresour. Technol. 72: 917.

[21] Prabha, K. P., Loretta, Y. L., Usha, R. K. 2007. An experimental study of vermi-biowaste compostingfor agricultural soil improvement. Bioresour. Technol., 99: 16721681.

[22] Sainz, M. T., Taboada-Castro, M. T. and Vilarino, A. 1998. Growth, mineral nutrition and mycorrhizalcolonization of red clover and cicumber plants grown in a soil amended with composted urban waste. Plant Soil, 205: 85-92.

[23] Goutam, K. C., Goutam Bhunia, B. and Susanta, K. (2011) The Effect of Vermicompost and Other Fertilizers on Cultivation of Tomato Plants. Journal of Horticulture and Forestry, 3, 42-45.

[24] Sanchez, A. P. and R. B. Leakey, 1997. Land use transformation in Africa: three determinants for balancing food security with natural resource utilization. Agron J. 7: 1523.

[25] Vlek, P. L., 1990. The role of fertilizers in sustaining agriculture in sub-Saharan Africa. Fert. Res. J. 26: 327-339.

[26] Stewart, W. M., D. W. Dibb, A. E. Johnston and T. J. Smyth, 2005. The contribution of commercial fertilizernutrients to food production. Agron J. 97: 1-6.

[27] Mengel, K. and E. A. Kirkby, 1996. Principles of plant nutrition. Panimo published corporation, New Delhi, India. 520 p.

[28] Lamps S (2000). Principles of integrated plant nutrition management system. In: Proc. Symp. Integrated plant nutrition management (Nov 8-10, 1999). NFDC, Planning and Development Division, Govt. of Pakistan 3-17.

[29] Aulakh MS, Grant CA (2008). Integrated nutrient management for sustainable crop production. The Haworth Press, Taylor and Francis Group: New York.

[30] Mahajan A, Bhagat RM, Gupta RD (2008). Integrated nutrient management in sustainable rice- wheatcropping system for food security in India. SAARC Journal of Agriculture 6: 2932.

[31] Roberts TL (2010). Nutrient best management practices: Western perspectives on global nutrient stewardship, 19th World Congress of Soil Science, Soil Solutions for a Changing World, 172-175, Brisbane, Australia. August 1-6.

[32] FAO (Food and Agriculture Organization), 2001. Lecture notes on the major soils of the world. Driessen, P., J. Deckers, and F. Nachtergaele, (eds.). Food and Agricultural Organizations, Rome, Italy. 334p.

[33] Mesfin Abebe, 1998. Nature and management of Ethiopian soils. Alemaya University, Ethiopia. 272p.

[34] Syers JK, Johnston AE, Curtin DC 2008: Efficiency of Soil and Fertilizer Phosphorus Use. Food and Agriculture Organization of the United Nations, Rome.

[35] Orozco, F. H., Cegarra, J., Trujillo, L. M. and Roig, A. 1996. Vermicomposting of coffee pulp using the earthworm Eiseniafetida: effects on $\mathrm{C}$ and $\mathrm{N}$ contents and the availability of nutrients. Biol. Ferti. Soils, 22: 162-166. 
[36] Gao, G. and C. Chang, 1996. Changes in cation exchange capacity and particle size distribution of soils associated with long- term annual applications of cattle feed lot manure. Soil Sci. J. 161: 115-120.

[37] Saikh, H., C. Varadachari and K. Ghosh, 1998. Effects of deforestation and cultivation on soil CEC and contents of exchangeable bases. A case study in Simplipal National Park, India. Plant and Soil J. 204: 67-75.

[38] Landon, J. R., 1991. Booker tropical soil manual: A Handbook for Soil Survey and Agricultural Land Evaluation in the Tropics and Subtropics. Longman Scientific and Technical, Essex, New York. 474p.

[39] Devi KN, Singh MS, Singh NG, Athokpam HS (2011). Effect of integrated nutrient management on growth and yield of wheat (Triticumaestivum L.). Journal of Crop and Weed 7 (2): 23-27.

[40] Lekshmanaswamy M., 2014. Effect of vermicompost on Jatropha curcas growth. SIR J Biol Environ Sci, 2014; 1 (1): 13-16.

[41] Lazcano, C. and Dominguez, J. (2010) Effects of Vermicompost as a Potting Amendment of Two Commercially- Grown Ornamental Plant Species. Spanish Journal of Agricultural Research, 8, 1260-1270.

[42] Theunissen J, Ndakidemi PA, Laubscher CP. 2010. Potential of Vermicompost produced from plantwaste on the growth and nutrient status in vegetable production. Intl J Phys Sci, 2010; 5: 1964-1973 